\title{
Special issue of clinical pharmacology: advances and applications in new protein therapeutics modulating tumor immunity
}

This article was published in the following Dove Press journal:

Clinical Pharmacology:Advances and Applications

25 November 2013

Number of times this article has been viewed

\author{
Arthur E Frankel \\ Department of Internal Medicine, \\ Simmons Comprehensive Cancer \\ Center, The University of Texas \\ Southwestern Medical Center, \\ Dallas, TX, USA
}

Until recent decades, the role of the immune system in harnessing tumor growth was based on anecdotal observations of increased cancers in immune-compromised patients, the benefits of graft-versus-leukemia in allogeneic stem cell transplants, and the limited but reproducible anticancer activity of several lymphokines, including interferon and interleukin (IL)-2. Vaccine studies and infusions of "activated" lymphocytes yielded variable clinical responses and disease control. An improved understanding of the molecular and cell mechanisms of the innate and adaptive immune system in cancerbearing animals and the discovery of an immune-suppressive tumor microenvironment then led to development and testing of a battery of new drug and cell-based approaches to trigger antitumor immunity. This issue of Clinical Pharmacology: Advances and Applications highlights some of the new protein-based compounds that are radically changing the cancer therapeutic landscape. The purpose of this collection of reviews is to inform the readership regarding the importance of the seismic change in cancer therapeutics and stimulate efforts to find novel niches and combinations of agents similar to recent advances in the application of cancer pathway inhibitors.

The elements in the immunosuppressive tumor microenvironment include cells (regulatory $\mathrm{T}$ cells, type 2 tumor-associated macrophages, myeloid-derived suppressor cells) and proteins (CTLA-4, PD-L1, galectin-9, IL-10, vascular endothelial growth factor, transforming growth factor beta, CD73, arginase, indoleamine 2,3dioxygenase). ${ }^{1}$ These work in concert to mitigate host innate and adaptive immune responses to tumor cells.

Remarkably, single targeted protein compounds have adequately shifted the tumor microenvironment to achieve durable remissions lasting years. We discuss below and in the included papers results with the bispecific antibody blinatumomab, the small molecular weight Toll-like receptor-8 agonist VTX-2337, the anti-CTLA4 antibody ipilimumab, immunocytokines such as L19IL2, Hu14.18-IL2, BC1-IL12, and L19-TNF, the anti-CD137 antibody BMS663513, and the trifunctional antibody catumaxomab. Both successes and challenges are noted.

Blinatumomab is a bispecific antibody reactive with CD19 and CD3. It is made of two single-chain antibody fragments connected by a five amino acid linker. The molecule creates an immune synapse between cytotoxic T-cells and malignant B-cells. Blinatumomab is administered as a 4-week continuous infusion at 5-15 $\mu \mathrm{g} / \mathrm{m}^{2} /$ day repeated every 6 weeks for up to four cycles. Reversible toxicities are cytokine release with fever, chills, dyspnea, hypotension, and central nervous system-related
Correspondence: Arthur E Frankel Department of Internal Medicine, Simmons Comprehensive Cancer Center, 220I Inwood Rd, Dallas, TX 75235, USA Email arthur.frankel@utsouthwestern. edu
Clinical Pharmacology:Advances and Applications 2013:5 I-3 Dovepress (c) (i) (5) 2013 Frankel. This work is published by Dove Medical Press Limited, and licensed under Creative Commons Attribution - Non Commercial (unported, v3.0) License. The full terms of the License are available at http://creativecommons.org/licenses/by-nd/3.0/. Non-commercial uses of the work are permitted without any further permission from Dove Medical Press Limited, provided the work is properly attributed. Permissions beyond the scope of the License are administered by Dove Medical Press Limited. Information on how to request permission may be found at: http://www.dovepress.com/permissions.php 
with seizures and encephalopathy. The drug yields $80 \%$ molecular complete remissions in patients with acute lymphoblastic leukemia and minimal residual disease and 29\% partial remissions in patients with refractory non-Hodgkin's lymphoma. Portell et al provide a timely and detailed review in this issue. ${ }^{2}$

VTX-2337 is a small molecular weight Toll-like receptor-8 agonist with a 2-aminobenzazepine core. VTX-2337 triggers innate immune activation. The molecule is dosed at $3 \mathrm{mg} /$ $\mathrm{m}^{2}$ subcutaneously on days 3,10 , and 17 , or on day 3 alone along with liposomal doxorubicin for patients with advanced epithelial ovarian cancer. Toxicities are considerable, and include fever, chills, hypotension, and flu-like symptoms. Hospitalizations have occurred secondary to innate immune system activation. Twenty-five percent of patients with ovarian cancer have shown stable disease. Brueseke and Tewari discuss this work in this issue. ${ }^{3}$

Ipilimumab is a human IgG1 antibody reactive with the extracellular domain of CTLA-4. Inhibition of CTLA-4 blocks the immune suppression of the CD80-CD28 costimulatory pathway. Ipilimumab is administered as a 90 -minute infusion of 3 or $10 \mathrm{mg} / \mathrm{kg}$ in $5 \%$ dextrose in water or normal saline and given every 3 weeks for four doses. Toxicities are autoimmune in nature and include dermatitis, hepatitis, hypophysitis, colitis, uveitis, arthritis, and neuritis. Severe autoimmune reactions are treated by stopping ipilimumab and giving corticosteroids, infliximab, mycophenolate mofetil, hormone replacement, or symptomatic treatments, as recommended in the manufacturer's protocol. The immune response control rate is $30 \%$, with $15 \%$ long-term survival in patients with metastatic melanoma. Acharya and Jeter detail the history and progress with this important immune modulator. ${ }^{4}$

L19IL2, Hu14.18-IL2, BC1-IL12, and L19-TNF are chimeric protein immunocytokines composed of an antiextradomain B fibronectin diabody fused to human IL-2 at its C-termini, a humanized anti-GD2 antibody fused to IL-2 at its heavy chain C-termini, a humanized anti-extradomain B fibronectin antibody with IL-12 p35s fused to the C-termini and IL-12 p40s disulfide linked to the molecule, and an anti-extradomain B fibronectin single-chain antibody fragment with tumor necrosis factor fused to the C-terminus, respectively. Each of these immunocytokines activates the immune system locally at the site of tumor cells. L19IL12 is given intravenously over one hour at $1.4 \mathrm{mg}$ /day; Hu14.18IL2 is given as $7.5 \mathrm{mg} / \mathrm{m}^{2}$ or $12.5 \mathrm{mg} / \mathrm{m}^{2}$ intravenously over 4 hours three times a week $\times 3$; BC1-IL12 is given as a 30 -minute intravenous infusion at $15 \mu \mathrm{g} / \mathrm{kg}$; and L19-TNF is given as an isolated limb perfusion at $650 \mu \mathrm{g}$ with melphalan.
Toxicities vary significantly. L19IL12 given systemically and L19-TNF given by isolated limb perfusion did not show reproducible side effects. Hu14.18-IL2 caused fever, chills, hypoxia, hypotension, and pain. BC1-IL12 produced fatigue, anemia, transaminasemia, fever, chills, headaches, and vomiting. Responses also differed with L19-IL2, which produced $83 \%$ stable disease in renal cell carcinoma and, in combination with dacarbazine, $28 \%$ partial remissions in melanoma. Hu14.18-IL2 achieved 58\% stable disease in patients with melanoma and, in a small study, $20 \%$ complete remissions in patients with neuroblastoma. BC1-IL12 only yielded 7\% partial responses in melanoma. L19-TNF with melphalan in limb perfusion produced $50 \%$ complete responses of limb melanoma lesions. List and Neri review this complex field. ${ }^{5}$

BMS663513 (urelumab) is a human anti-CD137 antibody. The antibody is an agonist for CD137, leading to cytotoxic T-cell stimulation. The drug is given at $1-10 \mathrm{mg} / \mathrm{kg}$ intravenously over 60 minutes every 3 weeks. Toxicities are fatigue, transaminasemia, neutropenia, rash, and diarrhea. In a Phase I study, there were $5 \%$ partial remissions and $7 \%$ stable disease in patients with melanoma. ${ }^{6} \mathrm{Li}$ and Liu provide a review of the preclinical and clinical development of urelumab to date. ${ }^{7}$

The last report concerns catumaxomab. Catumaxomab is a bispecific antibody with both murine and rat heavy and light chains reactive with EpCAM and CD3. It attracts T-cells, natural killer cells, and macrophages to epithelial tumor cells on the serosa of malignant ascites due to epithelial cancer. It is given as a 3-8-hour intraperitoneal infusion of $10-5,000 \mu \mathrm{g}$ for four doses. Toxicities are fever, abdominal pain, nausea, and vomiting. Ninety-six percent of ovarian cancer ascites are well controlled with this drug. Eskander and Tewari focus on the unique cavitary applications of this immune protein. ${ }^{8}$

Thus, this special issue documents some of the impressive advances in immune-modulating protein-based agents. In a single issue, we cannot encompass all the advances. In particular, use of PD1 and PD-L1 antibodies have provided groundbreaking results. ${ }^{9}$ New findings with the anti-phosphatidylserine antibody, bavituximab, suggest immune mechanisms of action. ${ }^{10}$ Inhibitors of TIM-3, chemokine receptor type 4, chemokine (C-C motif) ligand 1 , cyclooxygenase, arginase, nitric oxide synthase, indoleamine 2,3-dioxygenase, IL-10, transforming growth factor beta, and GITR and CD40 agonist antibodies are not reviewed in this issue, but are worthy of further analyses. Finally, with increased knowledge of the immune checkpoints 
and regulatory pathways in the tumor microenvironment, combinations of these different proteins warrant testing and assessment. Preliminary combinations of PD1 and CTLA4 inhibitors have shown promising clinical results. ${ }^{11}$ Patient selection based on the specific patient's tumor microenvironment offers a method to heighten the response rate, such as tumor cell PD-L1 expression. ${ }^{12}$ The editors and authors are excited about the likely central role of these diverse immune-modulatory proteins in cancer therapy in the next few decades.

\section{Disclosure}

The author reports no conflicts of interest in this work.

\section{References}

1. Devaud C, John LB, Westwood JA, et al. Immune modulation of the tumor microenvironment for enhancing cancer immunotherapy. Oncoimmunology. 2013;2:e25961.

2. Portell CA, Wenzell CM, Advani AS. Clinical and pharmacologic aspects of blinatumomab in the treatment of B-cell acute lymphoblastic leukemia. Clin Pharmacol. 2013;5 (Suppl 1):5-11.

3. Brueseke TJ, Tewari KS. Toll-like receptor 8: augmentation of innate immunity in platinum resistant ovarian carcinoma. Clin Pharmacol. 2013;5 (Suppl 1):13-19.
4. Acharya UH, Jeter JM. Use of ipilimumab in the treatment of melanoma. Clin Pharmacol. 2013;5 (Suppl 1):21-27.

5. List T, Neri D. Immunocytokines: a review of molecules in clinical development for cancer therapy. Clin Pharmacol. 2013;5 (Suppl 1):29-45.

6. Sznol M, Hodi FS, Margolin K, et al. Phase I study of BMS-663513, a fully human anti-CD137 agonist monoclonal antibody, in patients (pts) with advanced cancer (CA). J Clin Oncol. 2008;26 Suppl:3007.

7. Li SY, Liu Y. Immunotherapy of melanoma with the immune costimulatory monoclonal antibodies targeting CD137. Clin Pharmacol. 2013;5 (Suppl 1):47-53.

8. Eskander RN, Tewari KS. Epithelial cell-adhesion molecule-directed trifunctional antibody immunotherapy for symptom management of advanced ovarian cancer. Clin Pharmacol. 2013;5 (Suppl 1):55-61.

9. Hamid O, Robert C, Daud A, et al. Safety and tumor responses with lambrolizumab (anti-PD-1) in melanoma. $N$ Engl $J$ Med. 2013;369:134-144.

10. Yin Y, Huang X, Lynn KD, Thorpe PE. Phosphatidylserine-targeting antibody induces M1 macrophage polarization and promotes myeloid-derived suppressor cell differentiation. Cancer Immunol Res. 2013;1:1-13.

11. Wolchok JD, Kluger H, Callahan MK, et al. Nivolumab plus ipilimumab in advanced melanoma. $N$ Engl J Med. 2013;369:122-133.

12. Grosso J, Horak CE, Inzunza D, et al. Association of tumor PD-L1 expression and immune biomarkers with clinical activity in patients (pts) with advanced solid tumors treated with nivolumab (anti-PD-1; BMS-936558; ONO-4538). J Clin Oncol. 2013;31 Suppl:3016.
Clinical Pharmacology: Advances and Applications

\section{Publish your work in this journal}

Clinical Pharmacology: Advances and Applications is an international, peer-reviewed, open access journal publishing original research, reports, reviews and commentaries on all areas of drug experience in humans. The manuscript management system is completely online and includes a very quick and fair peer-review system, which is all easy to use.

\section{Dovepress}

Visit http://www.dovepress.com/testimonials.php to read real quotes from published authors. 